\title{
Potensi Sayur Besan sebagai Daya Tarik Wisata Warisan Gastronomi Betawi di DKI Jakarta
}

\author{
Dhika Rizki Ramadhan, Woro Priatini, Ilma Indriasari \\ Universitas Pendidikan Indonesia, Jl. Dr. Setiabudhi No. 229, Bandung 40154, Indonesia \\ Penulis.E-mail: dhikarama8@upi.edu (Dhika Rizki Ramadhan)
}

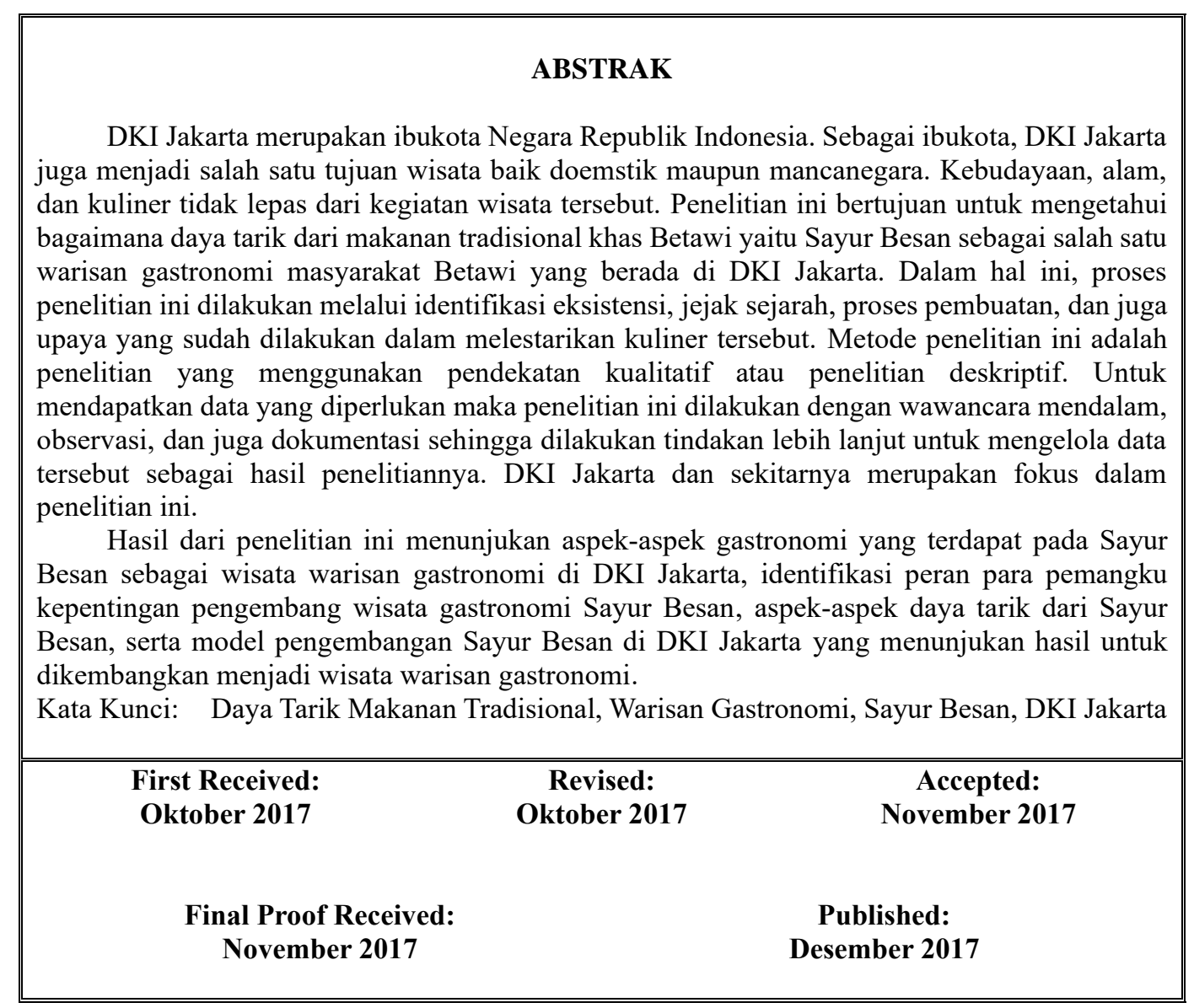




\section{Pendahuluan}

Pariwisata merupakan suatu kegiatan perjalanan yang bertujuan untuk rekreasi atau liburan. Di lapangan pariwisata dilakukan oleh sekelompok orang dan individu yang dilakukan berulang-ulang dan dalam waktu sementara ke suatu tempat. Hal tersebut menjadikan bahwa pariwisata merupakan suatu kegiatan yang tak bisa dipisahkan dari kehidupan manusia. Menurut Undang-Undang Republik Indonesia No. 10 Tahun 2009 Tentang Kepariwisataan pada pasal 1 ayat 3 dijelaskan bahwa pariwisata adalah berbagai macam kegiatan wisata dan didukung berbagai fasilitas dan layanan yang disediakan oleh masyarakat, pengusaha, pemerintah, dan pemerintah daerah. Menurut Oka A. Yoeti (1996:3) Industri pariwisata adalah kumpulan dari macammacam perusahaan yang secara bersamasama menghasilkan barang-barang dan jasajasa (goods and service) yang dibutuhkan wisatawan pada khususnya dan traveller pada umumnya, selama perjalanannya. Dari sisi ekonomi pariwisata di Indonesia mampu menjadi penyumbang terbesar devisa Negara kedua dimana pariwisata turut membantu peningkatan daya jual beli.

Produk pariwisata yang saat ini sedang berkembang yaitu gastronomi. Gastronomi merupakan salah satu bidang yang berfokus pada kegiatan makan dan minum yang di dalamnya terkandung kebudayaan, filosofi, sejarah, cara makan, penyajian, bahan baku, dan pengetahuan gizi dan beberapa aspek lain. Pada dasarnya gastronomi merupakan suatu ilmu yang mendalami suatu kuliner di suatu daerah yang di dalamnya mencakup nilai filosofis, geografis, sosial, adat istiadat, budaya, dan ekonomi. Selain itu gastronomi juga mengenalkan bagaimana menikmati kuliner sebagai karunia dari alam dan juga Tuhan Yang Maha Esa. Gastronomi menggambarkan pengaruh dari lingkungan (geografi dan iklim) dan budaya (sejarah dan etnis) terhadap komponen aroma, tekstur rasa dalam makanan dan minuman (Rao, Monin, \& Duran dalam Krisnadi, 2018).

Gastronomi dan juga kuliner di DKI Jakarta merupakan salah satu tujuan pariwisata yang paling populer karena hal ini selain merupakan salah satu kebutuhan wisatawan perkembangan kuliner di DKI Jakarta sangat dinamis sehingga dari masa ke masa selalu melahirkan tren kuliner terbaru yang menarik minat wisatawan. Dalam hal ini, kuliner Betawi juga menyimpan banyak kekayaan nilai budaya, sejarah, dan filosofi yang menjadikan kuliner Betawi juga merupakan tujuan wisata gastronomi. Gastronomi Betawi merupakan salah satu kekayaan budaya yang dimiliki oleh suku Betawi yang masih dikembangkan hingga saat ini. Pada dasarnya gastronomi betawi juga mengalami pengaruh tradisi dari etnis lain sehingga menyebabkan akulturasi budaya. Diantaranya adalah budaya Tionghoa, Arab, Melayu, Portugis, dan Belanda yang menyebabkan terbentuknya akulturasi budaya dalam penyajian makanan dan cara makannya sendiri seperti penyajian makanan tradisional di hari-hari besar keagamaan. Namun seiring tergerusnya lahan pertanian di DKI Jakarta kini beberapa makanan tradisional Betawi cukup sulit ditemukan disebabkan kelangkaan bahan baku. Beberapa gastronomi yang cukup dikenal diantaranya, yaitu Gado-gado Jakarta, Soto Betawi, Asinan Jakarta, Ketoprak Betawi, Lapis Legit, dan Manisan Kolang Kaling. Dan yang membuat gastronomi semakin menarik yaitu dari segala jenis bentuk makanannya memiliki sejarah, budaya, dan filosofi sehingga mampu menciptakan karakter yang lekat dengan masyarakat suku Betawi (Krisnadi, 2018).

Salah satu gastronomi Betawi yang cukup khas dan unik yaitu Sayur Besan. Makanan yang kaya akan rasa ini merupakan salah satu makanan yang cukup unik mulai dari namanya, sejarah, filosofi,dan identitasnya. Sayur ini memiliki 
bahan baku yang cukup jarang dalam berbagai masakan modern, yaitu terubuk. Selain itu, sayur ini kaya akan nutrisi seperti karbohidrat, protein, vitamin, dan mineral. Dibalik keunikannya sayur Besan sangat lekat maknanya dengan masyarakat Betawi disebut juga sayur ini menjadi salah satu gambaran karakter masyarakat Betawi.

Kekayaan Gastronomi yang dimiliki setiap daerah sangatlah kaya dan beragam dan bukan tidak mungkin erat kaitannya dengan identitas daerah bahkan Negara. Latar belakang yang kuat dari setiap kekayaan gastronomi menjadikan setiap daerah termasuk DKI Jakarta di dalamnya juga memiliki karakteristik budaya yang kuat dan perlu dipertahankan keberadaannya. Maka diperlukan langkah pengarsipan dan pengenalan yang terstruktur dari berbagai elemen agar masyarakat mengetahui kekayaan daerah tersebut. Oleh karena itu, penulis tertarik untuk melakukan penelitian mengenai "Sayur Besan Sebagai Daya Tarik Wisata Warisan Gastronomi Betawi di DKI Jakarta".

\subsection{Rumusan Masalah}

1. Bagaimana kandungan Komponen Gastronomi dalam Sayur Besan?

2. Bagaimana peran Salapan Cinyusu dalam pengembangan Daya Tarik Wisata Sayur Besan?

3. Bagaimana potensi gastronomi Sayur Besan sebagai Warisan Gastronomi di DKI Jakarta?

4. Bagaimana strategi dari Sayur Besan untuk dijadikan Daya Tarik Wisata Warisan Gatronomi di DKI Jakarta?

\subsection{Tujuan Penelitian}

1. Mengidentifikasi kandungan Komponen Gastronomi dari Sayur Besan.

2. Mengidentifikasi peran Salapan Cinyusu dalam pengembangan Daya Tarik Wisata Sayur Besan.

3. Mengetahui model potensi Sayur Besan sebagai Warisan Gastronomi.

4. Mengetahui strategi Wisata Gastronomi Sayur Besan di DKI Jakarta.

\subsection{Kegunaan Penelitian}

1. Penelitian ini diharapkan akan menambah wawasan kepada penulis mengenai Makanan Tradisional Sayur Besan baik filosofi, sejarah, dan tradisinya juga upaya melestarikannya supaya dapat menjadi manfaat.

2. Penelitian ini diharapkan dapat menambah informasi kepada para pembaca mengenai Makanan Tradisional Sayur Besan dan juga latar Budaya di dalamnya sehingga pembaca juga dapat ikut menerapkan hasil dari penelitian ini dalam pelestarian Sayur Besan.

\section{Kajian Literatur}

\subsection{Pariwisata}

Pariwisata merupakan suatu perjalanan yang dilakukan dari suatu tempat ke tempat lain yang bertujuan untuk kegiatan wisata dimana mengacu pada sebuah bentuk kegiatan. Pariwisata dan wisata merupakan sebuah bentuk kegiatan dimana wisata adalah suatu bentuk kegiatan yang didalamnya terdapat bentuk perjalanan yang dinamakan pariwisata. (Wijayanti, 2020:19).

Juga dijelaskan pengertian pariwisata yang dikemukakan oleh Koen Meyers (2009:3) yang menyebut bahwa pariwisata merupakan sebuah aktivitas perjalanan yang dilakukan dalam waktu yang sementara dari tempat tinggal menuju ke suatu daerah dengan beralasan bukan untuk menetap ataupun mencari nafkah selain hanya untuk bersenang-senang, memenuhi rasa ingin tahu, menghabiskan waktu senggang atau waktu libur serta tujuan lainnya. Dalam hal ini pariwisata lekat kaitannya dengan kegiatan rekreasi, pendidikan, dan kesehatan psikologis.

\subsection{Unsur-unsur Pariwisata}

Dalam perkembangannya, industri pariwisata harus mengembangkan konsepkonsep, panduan, dan peraturan dalam rangka tercapainya yang mampu meningkatkan jumlah pergerakan kegiatan pariwisata sendiri. Maka dari itu dalam 
pariwisata terdapat berbagai unsur yang telah dikaji oleh beberapa ahli.

Isdarmanto ( 2017:13) mengemukakan pendapatnya mengenai unsur-unsur pariwisata, bahwa di dalam pariwisata harus memiliki tiga unsur untuk dinyatakan sebagai gejala pariwisata, diantaranya:

1. Manusia, yaitu yang berperan sebagai unsur insani sebagai pelaku kegiatan wisata.

2. Tempat, merupakan unsur fisik yang juga dapat dicakup oleh kegiatan (pariwisata) itu sendiri.

3. Waktu, merupakan unsur tempo yang hingga menyelesaikan kegiatan (pariwisata) itu sendiri mulai dari perjalanan hingga lama waktu berdiam di tempat tujuan.

Selanjutnya, Pitana dan Diarta (2009:46) berpendapat bahwa dalam pariwisata terdapat beberapa unsur-unsur pokok yang umum disepakati dalam lingkup pariwisata, yaitu:

1. Traveler, merupakan orang yang melakukan perjalanan antar lokal.

2. Visitor, merupakan orang yang melakukan perjalanan ke suatu tujuan yang bukan merupakan daerah asalnya, kurang dari satu tahun, dan tujuan perjalanannya bukan untuk sebuah kegiatan mencari nafkah, pendapatan, atau mata pencaharian di tempat tujuan tersebut.

3. Tourist, yaitu bagian dari visitor yang menghabiskan waktu paling tidak satu malam satu hari di daerah yang dikunjungi.

\subsection{Gastronomi dan Wisata \\ Gastronomi}

Menurut Soeroso dan Turgarini (2020) dalam jurnal E-Journal of Tourism: Culinary versus Gastronomy memberikan pengertian sebagai berikut:

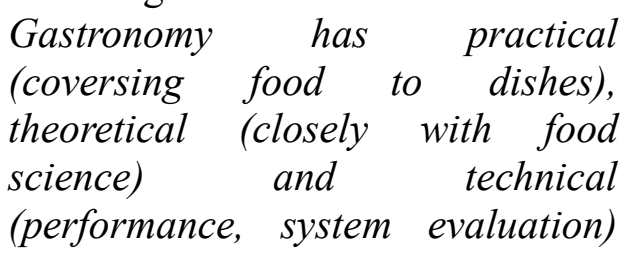

field of study, as well as food product development, molecular (a transformation of food physiochemical), geography, history, tourism and so on.

Menurut pendapatnya, gastronomi berada dalam bidang studi praktis yang mendalami tentang bagaimana mengubah bentuk bahan baku makanan menjadi hidangan, teori-teori tentang keilmuan pangan, teknis yang mengacu pada kinerja dan sistem pangan, serta pengembangan produk makanan, bentuk molekuler yang mencakup transformasi fisio-kimia pada makanan, geografi, sejarah, pariwisata dan sebagainya.

Gastronomi sendiri memiliki komponen dalam menentukan klasifikasi bidang-bidang kuliner yang dianggap sesuai dengan nilai gastronomi. Menurut Messakh dan Menteri Pariwisata Republik Indonesia (dalam World Tourism Organization, 2017:82) merumuskan bahwa Gastronomi Indonesia memiliki aspek-aspek yang selanjutnya dijadikan sebuah konsep yang menarik dan unik. Konsep tersebut dinamakan The Triangle Concept of Indonesian Gastronomy (Konsep Segitiga Gastronomi Indonesia). Aspek utama tersebut meliputi:

1. Food (makanan), merupakan aspek utama dari kegiatan gastronomi yang menjadi daya tarik utama.

2. Culture (budaya), kebudayaan yang terikat dengan kegiatan gastronomi yang menitikberatkan pada suatu tradisi penciptaan, penyajian, dan mencicipi makanan.

3. History (sejarah), menggambarkan sebuah perkembangan dari makanan sehingga menjaga cerita asli dan keotentikan dari makanan tersebut.

Selain itu, dalam menunjang aspekaspek tersebut di dalamnya terdapat beberapa unsur yang saling berpengaruh dan 
berkaitan antara aspek satu sama lain, diantaranya:

1. Ritual/ Ceremony (ritual/ upacara), merupakan unsur yang menjadi latar belakang dari terciptanya dan pengaplikasian suatu makanan dalam kegiatan budaya.

2. Spices (rempah/ bumbu), unsur yang menjadi pengikat antara terciptanya makanan dan sejarah perkembangannya lewat penggunaan bahan rempah dan bumbu serta makna di baliknya.

3. Storytelling (cerita), unsur yang menghidupkan sebuah aspek makanan dengan menyatukan aspek sejarah dan budaya untuk dapat diceritakan dan diwariskan.

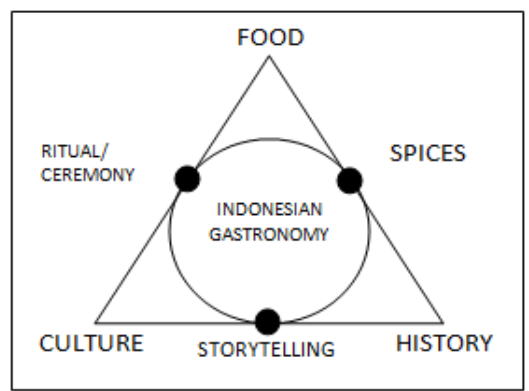

Gambar 2. 1 The Triangle Concept of Indonesian Gastronomy

Sumber: World Tourism Organization, 2017:82

Menurut López (2019), wisata gastronomi dapat diidentifikasi jika dalam suatu kegiatan wisata terjadi hal-hal sebagai berikut:

1. Kunjungan pasar, yaitu mendatangi pasar-pasar yang ada di suatu daerah untuk mengetahui aktivitas serta inventori hasil alam yang berada di suatu daerah.

2. Kunjungan rumah penduduk pedesaan yang bertujuan untuk mengetahui lingkup dan cara hidup keseharian di suatu daerah.
3. Adanya kegiatan jual beli kerajinan tangan dan produk ekologi suatu daerah.

4. Kunjungan ke suatu acara, ritual, atau festival suatu daerah, dan;

5. Lokakarya penyajian hidangan daerah.

\subsection{Salapan Cinyusu}

Turgarini (2018:217) dalam penelitiannya mengembangkan teori yang disebut Salapan Cinyusu merupakan aspek pemangku kepentingan dalam kegiatan wisata gastronomi agar mampu bersinergi mengembangkan kegiatan tersebut. Salapan Cinyusu akan menjadi dasar adanya gastronomi dikarenakan saling terkaitnya berbagai unsur-unsur di dalamnya yang memperkuat konstelasi gastronomi sendiri.

Berikut merupakan unsur-unsur dari Salapan Cinyusu yang menjadi pemangku kepentingan, yaitu

1. Pengusaha

2. Pemerintah

3. Pekerja

4. Pemasok

5. Pakar

6. Pemerhati

7. Penikmat

8. Lembaga Swadaya Masyarakat (NGO, Non Government Organization) atau LSM

9. Teknologi Informasi

\subsection{Makanan Tradisional}

Menurut Syarifuddin ( 2017), makanan tradisional merupakan sebuah tradisi yang memiliki peran dalam berbagai ritual, dalam hal ini makanan bukan hanya sekedar untuk dikonsumsi tetapi juga dijadikan sebuah media untuk menjalin komunikasi antara manusia dengan Tuhan atau leluhur, sesama manusia, dan manusia dengan alam. Lalu makanan tradisional mampu memberi citarasa yang khas yang dapat diterima dan dikonsumsi oleh masyarakat tertentu, dan dalam pembuatannya terkandung nilai budaya dalam bentuk keterampilan, sentuhan seni, tradisi dan selera.

Sedangkan menurut Fajri (2019), 
makanan tradisional merupakan makanan yang dikonsumsi untuk memenuhi kebutuhan nutrisi pada suatu masyarakat daerah dalam alur tradisi secara turun temurun.

\subsection{Sayur Besan}

Sayur Besan biasa dihidangkan oleh masyarakat Betawi pada saat acara lamaran dan atau akad nikah. Sayur ini melambangkan penghargaan kepada sang besan yaitu orang tua dari masing-masing pengantin sehingga menjadikan sayur ini bernama Sayur Besan dengan keistimewaannya. Bahan dan isi dari sayur ini terdiri dari ebi, kentang, soun, lalu dilengkapi dengan petai. Kuah santan semakin menambah rasa gurih pada sayur tersebut. Selain itu, ada bahan yang wajib ada dalam sajian sayur ini, yaitu terubuk atau telur tebu yang merupakan tanaman musiman. Dikarenakan semakin sulitnya menemukan terubuk, sayur ini juga semakin langka untuk ditemukan. (Ketaren, 2017:219).

Ada filosofi yang unikdibalik bahan utama dari Sayur Besan,yaitu terubuk. Jika terubuk dibuka, maka akan terlihat kumpulan seperti telur ikan. Butiran ini menggambarkan orang-orang yang berkumpul dalam satu wadah dan bersatu secara rukun karena ikatan pernikahan. (Pratomo, 2020).

\subsection{Pengembangan Daya Tarik Wisata Gastronomi}

Palupi dan Fitri (2019:55) merumuskan bahwa keberhasilan sebuah pengembangan wisata gastronomi atau kuliner didasari oleh adanya sinergi dari beberapa komponen dan unsur pengembangan dalam ekosistem pariwisata. Beberapa unsur-unsur tersebut diantaranya adalah:

1. Aspek Produk

Produk merupakan aspek utama dalam wisata kuliner yang menjadi bahan jual. Produk menjadi jalan untuk tercapainya kepuasan konsumen melalui bentuk fisik ataupun kegiatan yang dapat dinikmati wisatawan kuliner. Aspek produk terdiri dari beberapa unsur yaitu kekuatan nilai sejarah dan budaya, pengembangan cerita, pengemasan paket wisata, serta norma dan etika yang diikuti. Produk wisata kuliner harus bisa memberikan makna dan pengalaman bagi wisatawan.

2. Aspek Pasar

Pasar dalam kepariwisataan merujuk pada tren global yang berlaku. Hal ini dapat mempengaruhi intensitas wisatawan dikarenakan perkembangan produk wisata kuliner. Selain itu, analisis target pasar dan saluran pasar juga termasuk dalam aspek ini sehingga penyampaian informasi wisata kuliner dapat terarah dan tertuju pada masingmasing target yang sudah ditentukan. Aspek pasar harus mampu mengelola dan megendalikan kegiatan pasar yang mengikuti perkembangan teknologi melalui pengjangkauan beragam saluran pasar untuk mencapai berbagai kategori target pasar.

3. Aspek Sumber Daya Manusia

Sumber daya manusia dalam wisata kuliner merupakan peran penting dalam penggerakan kegiatannya. Sumber daya manusia dalam wisata kuliner juga harus mampu melibatkan masyarakat sekitar tujuan wisata kuliner tersebut. Lalu, aspek sumber daya manusia juga harus dilengkapi dengan adanya penguatan kapasitas dari kelompok masyarakat setempat untuk mengembangan sebuah wisata kuliner menjadi budaya dan bidang kegiatan ekonomi. Selain itu, pelaku usaha juga didorong untuk menjadi identitas cerita sebuah wisata kuliner.

4. Aspek Destinasi

Destinasi dalam wisata kuliner diharuskan melakukan zonasi. Yaitu sebuah wilayah yang mengacu pada perencanaan kawasan dan memperhatikan aturan pelestarian. Lalu, diperlukannya aksesibiltas untuk menjangkau tujuan wisata kuliner 
tersebut. Pengembangan destinasi wisata harus memperhatikan daya dukung kawasan seperti aturan budaya dan pelestarian. Terlebih pada sebuah kampung adat harus memperhatikan aturan-aturan adat serta melibatkan tokoh-tokoh adat dalam perencanaan dan pengembangannya.

5. Infrastruktur Pendukung

$\begin{array}{llr}\text { Dalam } & \text { wisata } & \text { kuliner, } \\ \text { infrastruktur pendukung meliputi } \\ \text { fasilitas }\end{array}$
fasilitas ataupun sarana yang menunjang wisatawan untuk menuju atau menikmati tujuan wisata tersebut. Dalam keberlangsungannya, pengadaan infrastruktur pendukung harus memperhatikan aspek pelestarian lingkungan dan budaya. Selain itu, juga perlu memperhatikan kebutuhan wisatawan termasuk anak-anak, perempuan, lansia, dan kelompok orang berkebutuhan khusus. Selanjutnya infrastruktur pendukung diharapkan bisa merespon perkembangan teknologi.

6. Aspek Kebijakan dan Tata Kelola Pengembangan wisata kuliner elibatkan beberapapemangku kepentingan dalam mengelola suatu wisata kuliner di kawasan administrasi. Dalam pengembangan wisata kuliner juga harus tetap mengacu pada peraturan daerah, peraturan pelestarian, dan aturan adat setempat. Sehingga dari kebijakan tersebut mampu menunjang tata kelola yang konsisten dalam pengembangan sumber daya manusia untuk mengahsilkan produk wisata kuliner berkualitas.

\section{Objek dan Metodologi}

\subsection{Objek Penelitian}

Penelitian ini menjadikan Sayur Besan sebagai objeknya dengan subjek penelitian seperti produsen Sayur Besan yang ada di sekitar DKI Jakarta, pakar, sejarawan khususnya di bidang kuliner, serta Pemerintah dan lembaga atau organisasi terkait untuk mendapatkan data secara aktual dan berkaitan yang bisa didapatkan di lapangan yaitu masalah yang mengenai makanan tradisional Sayur Besan di DKI Jakarta.

\subsection{Metode Penelitian}

Pada penelitian ini digunakan metode pendekatan kualitatif sebagai desain penelitiannya, disebabkan masalah yang diteliti bersifat sosial dan dinamis. Penelitian ini dapat dilakukan melalui pemahaman interaksi sosial dengan caracara seperti wawancara mendalam sehingga peneliti dapat menemukan pola-pola penelitian yang mendalam.

Menurut Siyoto (2015:27) penelitian kualitatif adalah penelitian yang hasilnya lebih menekankan pada aspek pemahaman mendalam terhadap suatu masalah daripada melihat permasalahan untuk diteliti secara general. Pada umumnya, metode penelitian ini menggunakan teknik analisis mendalam (indept analysis), masalah dikaji dari kasus per kasus disebabkan metodologi kualitatif meyakini bahwa sifat suatu masalah akan berbeda dengan satu masalah lainnya. Maka dari itu, data yang dikumpulkan harus lengkap berupa data primer dan sekunder sehingga dapat menghasilkan penelitian yang berkualitas.

\subsection{Partisipan Penelitian}

Partisipan penelitian merupakan pihak yang dituju untuk menjadi subjek penelitian atau sumber yang mampu memberikan informasi-informasi yang dibutuhkan peneliti secara rinci mengenai penelitiannya. Menurut Siyoto ( 2015:12) menyebutkan bahwa partisipan merupakan orang-orang yang bisa diwawancara, diobservasi, diminta dan memberikan data, pendapat, pemikiran, dan persepsinya. Dalam penelitian ini, pemilihan partisipan disesuaikan dengan tujuan penelitian yang dilakukan peneliti untuk memenuhi informasi-informasi yang dibutuhkan mengenai permasalahan Sayur Besan sebagai Warisan Gastronomi di DKI Jakarta. Partisipan menjadi subjek dari penelitian yang terdiri dari produsen Sayur Besan yang tersebar di sekitar DKI Jakarta, Lembaga Masyarakat terkait, dan juga masyarakat 
DKI Jakarta. Selain itu juga dengan sumber data lainnya dari pakar, asosiasi, dan juga perangkat Pemerintah Daerah yang bergerak di sektor yang diteliti oleh peneliti.

\subsection{Tempat Penelitian}

Tempat dalam penelitian ini dilaksanakan di beberapa daerah yang tersebar di DKI Jakarta. Daerah itu mencakup kawasan budaya seperti Lembaga Kebudayaan Betawi, selain itu daerah lokasi usaha kuliner Betawi dan juga beberapa daerah lainnya. Dapat diketahui dari daerah yang dipilih mencakup area-area yang berkaitan dari sisi kebudayaan juga dari sisi produksi. Selanjutnya dilakukan penelitian ke tempat pemerintahan untuk mendapatkan informasi kedaerahan yang lebih lengkap dan aktual.

\subsection{Teknik Analisis Data}

Pengumpulan data mencakup beberapa komponen yang bisa dikatakan sebuah data. Menurut Raco (2010:108) pengumpulan data bertujuan untuk menghasilkan data-data yang bersifat informatif yang berupa teks, foto, cerita, gambar, artifacts, dan bukan berupa angka hitung-hitungan, setelahnya data dikumpulkan setelah arah dan tujuan penelitian sudah jelas dan juga bila sumber data seperti informan atau partisipan sudah diintifikasi dan setuju untuk diminta informasi.

Sejalan dengan bentuk pendekatan penelitian kualitatif dan sumber data yang akan digunakan untuk penelitian "Sayur Besan sebagai Daya Tarik Wisata Warisan Gastronomi di DKI Jakarta" maka teknik pengumpulan data yang digunakan dalam penelitian ini mencakup wawancara mendalam, observasi, studi dokumentasi, dan studi literatur.

\section{Hasil dan Pembahasan}

\subsection{Komponen Gastronomi Sayur Besan}

Aspek- aspek gastronomi yang ditemukan di wisata gastronomi Sayur Besan berdasarkan wawancara dan observasi adalah sebagai berikut :

1. Food as Spices
Sayur Besan memiliki komposisi bahan baku seperti terubuk, petai, soun, kentang, dan bumbu halus seperti cabai, serai, bawang merah, bawang putih, dan terasi. Bahan-bahan tersebut merupakan hasil dari akulturasi budaya antar etnis yang berdiam di sekitaran DKI Jakarta. Selain itu, bahanbahan yang digunakan juga merupakan bahan yang berasal dari daerah di sekitar DKI Jakarta seperti Bogor, Sukabumi, Cianjur, dan beberapa daerah lainnya di Jawa Barat. Sayur Besan sendiri memiliki karakteristik rasa yang unik seperti gurih, sedikit pedas, dan manis. Bentuk visual dari Sayur Besan sendiri juga memiliki warna khas yaitu kuning kemerah-merahan dengan kuah yang tidak terlalu kental. Pada Sayur Besan dapat ditemukan ciri khas utama yang paling menonjol yaitu terubuk dan juga soun yang merupakan bahan baku utama. berdasarkan kandungan gizi yang ada pada Sayur Besan dapat ditemukan beberapa manfaat gizi di dalamnya. Berikut kandungan gizi yang ada pada Sayur Besan.

\begin{tabular}{|l|l|}
\hline \multicolumn{2}{|c|}{$\begin{array}{c}\text { Sayur Besan } \\
1\end{array}$} \\
\hline Energi & $1.587,93 \mathrm{kkal}$ \\
\hline Protein & $76,71 \mathrm{~g}$ \\
\hline Lemak & $49,5 \mathrm{~g}$ \\
\hline Karbohidrat & $228,8 \mathrm{~g}$ \\
\hline Kalsium & $4.263,24 \mathrm{mg}$ \\
\hline Fosfor & $1.513,64 \mathrm{mg}$ \\
\hline Besi & $51,03 \mathrm{mg}$ \\
\hline Vitamin A & $277,77 \mathrm{mg}$ \\
\hline Vitamin B1 & $1.022 \mathrm{mg}$ \\
\hline Vitamin C & $120,35 \mathrm{mg}$ \\
\hline
\end{tabular}

Sumber: Data Diolah Penulis, 2021

\section{Food as Ritual}

Pada penggunaan bahan baku tidak ada perubahan sampai saat ini. sebagai ciri khas dari Sayur Besan, penggunaan 
bahan baku utama yaitu terubuk tidak pernah digantikan dengan bahan apa pun ataupun dihilangkan penggunaannya. Dari segi rasa, beberapa pengolah Sayur Besan sudah cukup banyak yang menggunakan kaldu-kaldu kemasan untuk memperkuat rasa dari Sayur Besan. Meskipun begitu, penggunaan bumbu tersebut tidak mengubah rasa otentik dari Sayur Besan sehingga rasanya tetap sama. Dalam pengolahan Sayur Besan, tidak ada proses khusus dan hanya menggunakan cara-cara memasak pada umumnya. Pada penggunaan alat-alat pengolahan Sayur Besan masih menggunakan alat-alat umum memasak. Tidak ada perubahan yang pasti dalam penggunaan alat-alat pengolahan Sayur Besan dengan alat yang berbahan besi atau pun kayu. Di antaraya seperti panci, talenan,cobek, saringan santan, pisau, spatula, sendok sayur, dan kompor. Sayur Besan sendiri disajikan dengan beberapa sajian lainnya. Pada saat disajikan sebagai makan siang, Sayur Besan seringkali disajikan bersama menu pendamping seperti kerupuk, emping, acar, dan sambal lalu disantap bersama dengan nasi. Untuk sajian pendamping biasadisajikan semur, ayam goring, pepes ikan,dan beberapa menu khas lainnya. Menu pendamping yang disajikan tidak terpaku pada aturan tertentu dikarenakan menyesuaikan dengan selera penikmatnya. Dalam acara-acara tertentu dan sebagai hantaran, Sayur Besan biasa disandingkan dengan makanan lain yang khususnya kue-kue manis. Beberapa di antaranya yaitu sperti sengkulun dan juga dodol Betawi

3. Culture as Ritual

Dalam pengolahan Sayur Besan tidak diperlukan ritual-ritual khusus dalam prosesnya. Yahya Andi Saputra menjelaskan bahwa proses pengolahan makanan yang menggunakan ritual biasanya hanya terdapat pada upacara- upacara dan makanan tertentu. Sayur Besan sendiri pada umumnya disajikan pada upacara adat atau acara-acara besar. Dalam pernikahan masyarakat Betawi, Sayur Besan juga sering dijadikan menu utama sebagai jamuan kepada tamu yang disajikan di Meja Nyai. Biasanya, dalam sebuah kegiatan makan Sayur Besan disajikan sekaligus bersamaan dengan lauk-pauk lainnya dengan Sayur Besan menjadi fokus utamanya. Penataannya Sayur Besan diletakkan di tengahtengah dan dilingkari dengan lauk-pauk lain seperti pepes, ayam goring, tempe dan tahu goring, sambal, acar, dan lainnya.

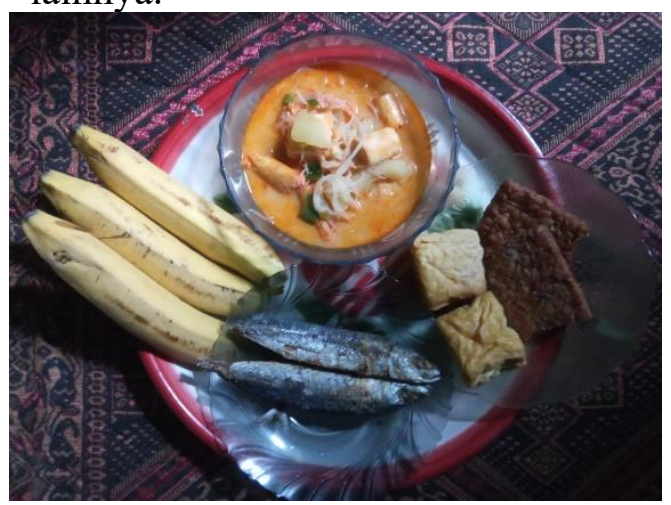

Gambar 4. 1 Penyajian Sayur Besan dalam hajatan

Sumber: Dokumentasi Pribadi, 2021

4. Culture as Storytelling

Berdasarkan pemaparan narasumber, Sayur besan sudah lekat menjadi sebuah identitas masyarakat Betawi. Namun lebih spesifik lagi, masyarakat yang sangat identik akan kehadiran Sayur besan adalah masyarakat Betawi Pinggir atau pinggiran kota DKI Jakarta. Dalam perkembangannya, Sayur Besan dijadikan bagian dari pernikahan masarakat Betawi. Sayur Besan dijadikan sebuah hantaran dari orang tua calon mempelai wanita kepada orang tua calon mempelai pria sebagai balasan hantaran yang diberikan oleh orang tua calon mempelai pria dalam prosesi lamaran, prosesi ini disebut tande putus. Selain itu, dalam prosesi tersebut memberikan simbol dari calon 
mempelai wanita bahwa pihak calon mempelai wanita sudah siap menerima segala konsekuensi untuk menerima pihak calon mempelai laki-laki. Dari pihak calon mempelai laki-laki sendiri, Sayur Besan dan hantaran lainnya dibagikan kepada keluarga, saudara, dan tetangga sebagai bentuk undangan untuk ikut mengantar pihak calon mempelai pria ke kediaman calon mempelai wanita untuk selanjutnya melakukan akad nikah atau ijab qobul, dan prosesi ini disebut ngerudat atau ngebesan.

5. History as Spices

Penamaan Sayur Besan ini disebabkan makanan ini selalu dihadirkan pada saat ritus pernikahan masyarakat Betawi. Besan sendiri merujuk pada sebutan orang tua dari kedua calon mempelai. Pada mulanya, Sayur Besan ini memang menjadi hantaran dari orang tua calon mempelai wanita kepada orang tua calon mempelai pria. terciptanya Sayur Besan ini dikarenakan akulturasi budaya antar etnis yang berdiam di tanah Betawi. Sayur Besan juga cukup berkaitan dengan kebudayaan etnis Tionghoa. Masyarakat lokal memadukan bahan yang sering digunakan antar etnis tersebut dalam pengolahan makanan sehingga menjadi sebuah perpaduan makanan yang bernama Sayur Terubuk atau Sayur Besan.

6. History as Stroytelling

Sayur Besan sudah diwariskan dalam bentuk fisiknya maupun tutur cerita atau arsip tertulis. Sayur Besan berkembang di medio 2000-an dikarenakan beberapa warung makan yang menjual dan menghidupkan kembali makanan tersebut., Terdapat beberapa arsip Sayur Besan yang terdiri dari berbagai dokumentasi visual, narasi-narasi cerita dan kesejarahan, serta pencatatan sebagai warisan budaya tak benda bersamaan dengan beberapa ikon budaya Betawi lainnya. Sayur Besan tercatat sebagai warisan budaya tak benda dari Kementerian Pendidikan dan
Kebudayaan dengan nomor registrasi 201400123 pada tahun 2014. Data tersebut tertuang dalam Surat Keputusan Kementerian Pendidikan dan Kebudayaan nomor 270/P/2014 tentang Warisan Budaya tak benda. Dalam surat keputusan tersebut, dilampirkan bahwa Sayur Besan ditetapkan sebagai warisan budaya tak benda yang berasal dari DKI Jakarta bersamaan dengan kebudayaan Betawi lain seperti Upacara Babarit, Nasi Uduk, Kerak Telor, Gabus Pucung, Roti Buaya, Bir Pletok, dan Blenggo (Kemendikbud RI, 2014)

\subsection{Peran Salapan Cinyusu}

Berikut adalah hasil dari wawancara dan observasi yang telah dilakukan oleh penulis mengenai peran Salapan Cinyusu:

1. saat ini usaha yang dijalankan merupakan rumah makan yang khusus menyajikan masakan khas Betawi. Di rumah makan Dapur Betawi ini memiliki tiga menu unggulan yaitu Gabus Pucung, Pecak, dan juga Sayur Besan. Selain itu, elemen lain yang ditawarkan di rumah makan ini berfokus pada masakan Betawi saja. Dalam penjualan Sayur Besan sendiri rumah makan ini tidak memiliki cara khusus dalam upaya pemasarannya. Penjual hanya memberikan informasi mengenai menu-menu yang disajikan serta penikmat Sayur Besan mendatangi secara langsung ke rumah makan Dapur Betawi tersebut.

2. Pemasok

Dalam memenuhi persediaan bahan baku utama pemasok mengambil bahan baku yang telah disuplai dari perkebunan terubuk di daerah Sukabumi. Pada umumnya bahan baku tersebut memang berasal dari daerah Jawa Barat dan sangat jarang untuk ditemukan di DKI Jakarta atau pun sekitarnya. Meskipun di Parung sebagai lokasi pemasok menjajakan dagangannya masih terdapat orangorang yang masih menanam terubuk tetapi tidak dapat memenuhi suplai 
kebutuhan bahan baku tersebut.

3. Pemerintah

Pemerintah DKI Jakarta sendiri sudah melakukan beberapa langkah dalam melestarikan Sayur Besan. Pemerintah menggalakkan promosi mengenai makanan tradisional dalam bentuk edukasi, imbauan, dorongan terhadap pelaku usaha, serta endorsement kepada public figure agar masyarakat kembali mengonsumsi makanan asal daerahnya sendiri.

4. Pakar dan Akademisi

Saat ini sayur besan sangat cocok untuk dijadikan wisata gastronomi menurut pakar gastronomi. Sayur Besan sangat unik sehigga memiliki storytellingnya sendiri dan dapat meningkatkan potensi wisata gastronomi di DKI Jakarta. Selain itu, Sayur Besan sangat jarang ditemukan di daerah lain sehingga hal ini dapat menjadikannya sebagai daya tarik wisata khas daerah DKI Jakarta. pakar gastronomi serta akademisi di bidang tersebut, pernah melakukan kerjasama dengan Pemerintah Provinsi DKI Jakarta dalam melakukan penelitian tentang Sayur Besan. Dari hasil kerjasama tersebut diketahui sebagai langkah inventarisasi budaya sehingga Sayur Besan mampu dijadikan sebagai warisan budaya tak benda yang berasal dari DKI Jakarta.

5. Pemerhati

Pemerhati sendiri memiliki peran dalam menciptakan gambaran tersebut. Beberapa cara di antaranya dengan membuat ulasan-ulasan mengenai Sayur Besan. Yahya Andi Saputra menyampaikan bahwa sudah cukup terdapat ulasan-ulasan terkait Sayur Besan untuk disampaikan kepada masyarakat. Namun, hal itu sendiri masih memiliki beberapa masalah dalam keberlangsungannya, seperti kurangnya literasi masyarakat khususnya dalam bidang gastronomi yang menyebabkan informasi-informasi Sayur Besan yang terdapat pada ulasan tersebut kurang diserap oleh beberapa kalangan.

6. Penikmat

Dapat diketahui bahwa alasan mengonsumsi Sayur Besan di antaranya karena beberapa hal. Makanan tersebut merupakan makanan yang berkembang di suatu daerah sehingga menjadi suatu kebiasaan masa kecil dari penikmat Sayur Besan. Selain itu, dikarenakan keunikan Sayur Besan tersebut juga yang menambah keingintahuan penikmat untuk mencicipi Sayur Besan tersebut. Untuk membuat Sayur Besan tetap dikonsumsi oleh banyak konsumen, narasumber memaparkan bahwa perlunya pengenalan kembali Sayur Besan ke masyarakat luas. Pengenalan ini bisa dilakukan dengan beberapa cara di antaranya mengajak masyarakat untuk mau mencoba Sayur Besan di warung yang masih menyediakan, selanjutnya mengangkat Sayur Besan sebagai menu di restoranrestoran, dan juga menyajikannya dalam ritual adat terkait.

7. NGO/Komunitas

Dalam pengembangan kegiatan wisata gastronomi sudah dilakukan kegiatan perjalanan wisata yang berbentuk paket. HPI merancang sebuah paket perjalan kuliner yang di dalamnya bertujuan ke kuliner-kuliner daerah, turunan, maupun mancanegara. Sayangnya dalam kegiatan yang dibuat belum melibatkan Sayur Besan dikarenakan sangat langkanya penjual Sayur Besan dan tujuan daerah kuliner yang menyediakan Sayur Besan di DKI Jakarta. Sehubungan dengan kegiatan wisata gastronomi, HPI juga merancang program pelestarian untuk keberlangsungan wisata gastronomi atau kuliner. HPI melakukan eksplorasi ke rumah-rumah warga setempat ataupun mendatangi restoran dan rumah makan yang menyajikan sajian khusus agar dapat menginventarisasi denah wisata gastronomi di DKI Jakarta. Seluruh anggota HPI DKI Jakarta 
berupaya mengeksplor tujuan gastronomi yang juga melibatkan Sayur Besan di dalamnya namun perlu penggalian ifnormasi lebih lanjut.

8. Teknologi Informasi

Di bidang media informasi digital, sudah dilakukan upaya pengenalan Sayur Besan kepada masyarakat dari media Kompas.com. Dalam upaya pengenalan Sayur Besan, Kompas.com banyak mempublikasikan artikel-artikel yang di dalamnya bukan hanya berkaitan dengan resep dan bahan baku tetapi juga edukasi mengenai latar belakang dari Sayur Besan itu sendiri baik gambaran kebudayaan, maknamakna dari Sayur Besan, serta sejarah Sayur Besan. Dapat ditemukan artikelartikel mengenai Sayur Besan di kanal Food di website Kompas.com. Dalam website tersebut terdapat beberapa artikel mengenai Sayur Besan, di antaranya mengenai resep Sayur Besan, filosofi Sayur Besan dalam pernikahan Betawi, tradisi yang menyajikan Sayur Besan, serta keistimewaan Sayur Besan sebagai menu Betawi kuno.

\subsection{Potensi Sayur Besan sebagai Wisata Warisan Gastronomi}

1. Keunikan

Komposisi dan karakteristik rasa Sayur Besan sendiri menggunakan bahan baku yang cukup langka namun menjadi sebuah kekhasan dari produk tersebut. Terubuk merupakan bahan baku utama dalam pembuatan Sayur Besan yang memberikan sensasi tersendiri saat menyantapnya. Bahanbahan tersebut dipadukan dengan berbagai macam bahan baku lain seperti soun, petai, kentang dan bumbu khas sehingga menciptakan karakteristik rasa yang gurih, sedikit manis, dan juga sedikit pedas. Selain bentuk fisiknya, Sayur Besan memiliki keunikan karena penamaan dan penyajiannya. Nama Sayur Besan cukup unik untuk didengar konsumen dan dapat menarik minat konsumen pada makanan tersebut..
Namun utamanya makanan ini cukup sering disajikan pada acara pernikahan. Sayur Besan sering dijadikan sebuah sajian dalam prosesi hantaran oleh keluarga pengantin dalam prosesi yang bernama ngenjot.

2. Keaslian

Sayur Besan sendiri memiliki karakteristik rasa yang cukup otentik. Rasa manis, gurih, dan pedas yang ada pada Sayur Besan dapat digambarkan sebagai rasa yang cukup identik pada makanan tersebut. Meskipun rasa tersebut juga terdapat pada beberapa makanan lain tetapi perpaduan rasa pada Sayur Besan memiliki kecocokan tersendiri dengan komposisi lain di dalamnya. Terubuk dalam Sayur Besan memberikan perpaduan yang cukup identik dengan tekstur lembut dan sedikit krispi serta rasa gurih pada bahan tersebut memberikan karakteristik rasa tersendiri pada Sayur Besan. Bahan baku tersebut juga cukup jarang ditemukan pada olahan makanan lain pada umumya. Sayur Besan sendiri juga disampaikan bahwa makanan ini memiliki asal-usul dari daerah sebaran masyarakat Betawi.

3. Kelangkaan

Belum ada makanan yang memiliki kemiripan dengan Sayur Besan secara bentuk fisiknya. Namun dalam karakteristik rasa Sayur Besan memiliki cita rasa yang hampir mirip dengan beberapa makanan Betawi lainnya. Dijelaskan bahwa rasa Sayur Besan memiliki kemiripan dengan lontong sayur namun tidak akan bisa dikatakan sebagai Sayur besan jika tidak ada terubuk di dalamnya. Selain itu juga ditemukan beberapa makanan yang menggunakan bahan baku yang sama namun memiliki cita rasa yang cukup berbeda dengan Sayur Besan seperti Sayur Sambal Godog, sayurLilin, dan Sayur Kare Jawa.

4. Keutuhan dalam menjaga ketahanan Sayur Besan 
masih perlu dilakukan pengembangan kembali. Sampai saat ini belum ditemukan adanya sanggar-sanggar budaya yang khususnya mewadahi pelestarian dari makanan tradisional khususnya Sayur Besan. Dari sisi produk Sayur Besan sendiri masih kurangnya kegiatan pembudidayaan bahan baku utama yaitu terubuk. Di DKI Jakarta sendiri sudah jarang ditemukan daerah-daerah penghasil tumbuhan tersebut sehingga hal ini juga mempengaruhi produksi keberlanjutan dari Sayur Besan.

\subsection{Strategi Sayur Besan sebagai Daya Tarik Wisata Gastronomi di DKI Jakarta}

1. Aspek Produk

Dalam perkembangan Sayur Besan tidak ada yang kurang dari sisi produk baik dari komposisi maupun presentasi. dalam menjaga orisinalitas dari Sayur Besan tidak perlu ada yang dikurangi atau pun ditambahkan sehingga cita rasa dari Sayur Besan masih sama dan terjaga. Penggunaan bahan baku harus tetap menyesuaikan dengan resep yang sudah ada dari masa ke masa agar tidak merubah ciri khas dari makanan tersebut dan juga nilai-nilai kebudayaan di dalamnya. Perlu dilakukan beberapa pendekatan yang sesuai dengan berbagai kalangan sehingga diperlukan beberapa strategi seperti penggunaan media sosial dan media teknologi lainnya dalam pengenalan Sayur Besan, memberi promosi-promosi menarik terkait Sayur Besan, dan juga melakukan inovasi perjalanan wisata yang melibatkan Sayur Besan. Bentuk penyajian yang terkesan lampau dapat dikembangkan menjadi lebih baru salah satunya dari pengemasan produknya yang bukan hanya sebagai produk siap makan tetapi juga dapat dikembangkan menjadi sebuah oleh-oleh yang juga dapat dikonsumsi oleh masyarakat luar daerah.

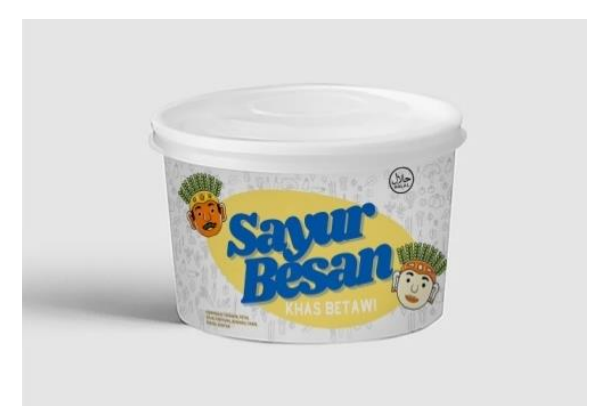

Gambar 4. 2 Kemasan mangkuk Sayur Besan

Sumber: Dokumentasi Pribadi, 2021

Dalam menjadikan Sayur Besan sebagai produk wisata, perlu ditingkatkan sinergi dari berbagai pihak terkait dalam pengembangannya. Pemangku kebijakan dapat mendorong masyarakat agar lebih ikut berperan dalam pelestarian Sayur Besan dalam menjaga ketahanan produknya.

2. Aspek Pasar

Sayur Besan sampai saat ini masih diminati oleh banyak masyarakat baik konsumen atau yang belum pernah mencicipi. Hal ini bisa dibuktikan dengan ramainya pengunjung ke tempat-tempat yang menyediakan Sayur Besan. Sayangnya meskipun masih banyak yang meminati Sayur Besan sampai saat ini belum ada program wisata gastronomi khusus yang menyediakan perjalanan mengenai Sayur Besan. Sampai saat ini belum ditemukan informasi-informasi baik digital atau pun secara tertulis terkait program wisata gastronomi tersebut. secara produk dapat ditemukan beberapa informasiinformasi di media sosial atau pun website terkait produk Sayur Besan seperti rumah makan yang menyediakan, resep, dan juga informasi cerita dan edukasi dari Sayur Besan. Atas dasar hal tersebut, penggunaan informasi ini masih perlu dikembangkan kembali ke dalam program wisata gastronomi dengan tujuan memperlebar jangkauan informasi serta promosi kepada konsumen dan penikmat wisata 
gastronomi Sayur Besan. Target pasar dari Sayur Besan sendiri dapat menyasar ke seluruh kalangan baik tua sampai muda dan tidak terbatas pada suatu golongan. Dalam hal pemasaran saat ini masih terfokus pada kalangan orang tua yang menyukai makanan tersebut maka dari itu perlu dikembangkan kembali bentuk promosi dan pengenalannya agar dapat terjangkau oleh berbagai kalangan.

3. Aspek Sumber Daya Manusia

dalam kegiatan wisata gastronomi Sayur Besan diperlukan adanya standarisasi sumber daya manusia. Hal ini dikarenakan perlunya kesamaan dari pengelolaan kegiatan wisata tersebut sehingga menciptakan ketahanan ciri khas serta keunikan dari produk wisata gastronomi tersebut. Dalam produksi Sayur Besan, diperlukan sumber daya yang mumpuni dalam masak-memasak dan juga memiliki pengetahuan serta latar dari Sayur Besan sendiri. Hal tersebut dimaksudkan agar cita rasa Sayur Besan tidak berubah meskipun dikelola secara besar dan masif. Begitu pun pelaku wisata diharapkan dapat meningkatkan standar sumber daya manusia yang kompeten dalam merancang strategi pengelolaan wisata gastronomi Sayur Besan. Sumber daya tersebut bukan hanya ikut dalam pengelolaan wisata gastronomi dimana masyarakat sebagai sumber daya manusia juga diajak untuk berperan dalam kegiatan wisata tersebut agar dapat melestarikan Sayur Besan sebagai produknya.

4. Aspek Destinasi

Di DKI Jakarta sendiri belum ada destinasi khusus gastronomi yang menyediakan kegiatan wisata khususnya Sayur Besan. Pada umumnya makanan-makanan tradisional khas DKI Jakarta memiliki kedaerahannya masing-masing dan tidak terkumpul pada satu pusat sehingga untuk menemukannya wisatawan harus mengunjungi daerah yang menyediakan makanan tersebut. berpendapat sejauh ini belum ditemukan sentra-sentra atau pasar khusus yang menyediakan Sayur Besan di DKI Jakarta. Hal ini dikarenakan penyebaran bahan baku Sayur Besan yang lebih massif di kawasan pinggiran Jakarta. Berdasarkan temuan penulis, dapat ditemui satu-satunya rumah makan yang masih menyediakan Sayur Besan di DKI Jakarta yaitu Dapur Betawi yang terletak di Karang Tengah, Jakarta Selatan.

5. Infrastruktur Pendukung

Infrastruktur pendukung di DKI Jakarta sendiri sudah cukup terpenuhi untuk wisata gastronomi Sayur Besan. Beberapa di antaranya yaitu fasilitasfasilitas kebutuhan wisatawan yang terdapat di beberapa tempat yang berpotensi menjadi tujuan wisata gastronomi seperti Perkampungan Budaya Betawi Setu Babakan dan rumah produksi Sayur Besan. Di kawasan tersebut juga terdapat fasilitasfasilitas yang bisa digunakan sekaligus memberdayakan warga sekitar dengan menjadikan rumah warga sekitar sebaai tempat pelatihan mengolah Sayur Besan. Beberapa fasilitas penunjang lainnya juga cukup tersedia di dua kawasan tersebut untuk memenuhi kebutuhan perjalanan wisata gastronomi seperti ATM center, masjid, fasilitas air bersih, tempat sampah, pusat informasi, serta wahana rekreasi penunjang lainnya. Sarana transportasi yang dapat digunakan juga sudah cukup tersedia dan juga bervariasi. Beberapa transportasi yang ada di sekitar destinasi wisata gastronomi Sayur Besan juga sudah tersedia dan cukup terintegrasi untuk memudahkan wisatawan untuk menjangkau satu persatu kawasan tersebut. Beberapa di antaranya seperti stasiun kereta komuter yang berada di daerah Lenteng Agung dan juga Kebayoran Lama yang 
terdekat dengan destinasi. Selain itu, penumpang dapat melanjutkan perjalanan dengan angkutan kota atau angkot yang tersedia di kawasan tersebut. Bus-bus transjakarta juga sudah tersedia dengan melewati ruterute stasiun dan destinasi wisata gastronomi, hal ini cukup memudahkan bagi wisatawan yang melakukan perjalanan wisata gastronomi menggunakan transportasi umum.

6. Aspek Kebijakan dan Tata Kelola

Dalam penyelenggaraan kegiatan wisata gastronomi diharapkan Pemerintah Daerah terlebih dahulu menyusun kebijakan dan peraturan terkait pelestarian dari objek terkait yaitu Sayur Besan. Selanjutnya, Pemerintah diharapkan lebih giat lagi dalam menggalakkan penyadaran dan penyampaian informasi kepada masyarakat mengenai wisata gastronomi Sayur Besan sendiri. Informasi integratif dapat disampaikan melalui beberapa pelaksanaan seperti edukasi-edukasi mengenai Sayur Besan, penyelenggaraan festival yang menyajikan Sayur Besan, hingga pada akhirnya dapat dirangkai menjadi sebuah kegiatan wisata gastronomi. Selebihnya diharapkan ada kontribusi dari pemangku kepentingan terkait dalam menjaga keberlanjutan wisata gastronomi Sayur Besan. Dari segi pengelolaan, pada saat ini diperlukan pengetahuan serta wawasan dari para pelaku wisata gastronomi Sayur Besan mengenai makanan tersebut. Sumber daya manusia yang berkecimpung di dalamnya diharapkan lebih mengenal serta memahami latar belakang dari kegiatan wisata gastronoi tersebut ataupun dari Sayur Besan sendiri.

\section{Simpulan dan Saran}

1. Perlu adanya langkah-langkah pengarsipan dari latar belakang Sayur Besan. Seluruh masyarakat hususnya masyarakat Betawi diharapkan ikut berperan dalam menjaga nilai tradisi, filosofi, dan catatan sejarah dari Sayur Besan sendiri. Selain itu, beberapa ritual serta tradisi yang melekat pada Sayur Besan dapat diupayakan untuk dihidupkan kembali. Hal tersebut bertujuan untuk tetap menciptakan kesadaran masyarakat akan kekayaan budaya dan tradisi daerah setempat.

2. Perlu ditingkatkan integrasi peran antar pihak dalam langkah penyediaan kegiatan wisata gastronomi yang berkelanjutan dan terciptanya pengelolaan yang inklusif. Penyusunan kebijakan dan peraturan juga diperlukan agar mengajak berbagai pihak dan masyarakat ikut berperan dalam melestarikan Sayur Besan di DKI Jakarta. Dalam hal pengelolaan dapat diupayakan permudahan distribusi bahan baku yang mudah ditemui di DKI Jakarta sehingga juga meningkatkan nilai ekonomi masyarakat daerah. Selanjutnya, menggalakkan dorongan kepada pelaku usaha dan pihak-pihak terkait agar dapat meningkatkan efektifitas produksi.

3. Dalam menjaga ketahanan Sayur Besan perlu dikembangkan upayaupaya pelatihan kepada tenaga penglola dari Sayur Besan itu sendiri. Salah satu caranya dengan menyediakan sanggar atau tempat pelatihan yang dapat digunakan oleh pengelola dan juga bisa menjadi sarana belajar mengolah Sayur Besan untuk umum. Begitu juga dalam pengembangan pembudidayaan bahan baku sehingga dapat meningkatkan keberlanjutan wisata gastronomi yang berasal dari perputaran sumber alam di daerah tersebut. Lalu, Sayur Besan dapat diupayakan untuk dijadikan ikon gastronomi di DKI 
Jakarta agar dapat meningkatkan upaya dari berbagai pihak dalam menjaga ketahanan dan kelestariannya. Beberapa cara yang bisa dilakukan seperti menginventarisasi dalam kegiatan dan acara-acara kebudayaan daerah, selain sebagai bentuk pelestarian juga dapat sekaligus menjadi daya tarik wisatawan.

4. Diperlukan pengembangan produk Sayur Besan seperti mengembangkan pengemasan dan juga inovasi pengolahan produk Sayur Besan sendiri seperti menjadikannya sebagai bumbu instan yang bisa digunakan kapan pun dan oleh siapa saja. Selain menambah nilai artstik, hal tersebut dapat meningkatkan nilai ekonomi dan pemberdayaan UMKM setempat. Kegiatan wisata gastronomi Sayur Besan sendiri dapat dikembangkan kepada seluruh kalangan dengan menyediakan beberapa inovasi dan beberapa fasilitas perjalan wisata. Selanjutnya, perlu meningkatkan cara-cara pemasaran Sayur Besan sendiri. Para pemangku kepentingan harus kreatif dalam meningkatkan pemasaran dengan memanfaatkan media-media informasi dan promosi yang ada dan ditargetkan kepada konsumen secara menyeluruh.

\section{Referensi}

Dr. Sandu Siyoto, SKM, M. K., \& M. Ali Sodik, M. A. (2015). Dasar Metodologi Penelitian. In Dasar Metodologi Penelitian. Sleman: Literasi Media.

Isdarmanto. (2017). Dasar-Dasar Kepariwisataan dan Pengelolaan Destinasi Pariwisata.

Kemendikbud RI. Surat Keputusan Kementerian Pendidikan dan Kebudayaan tentang warisan Budaya Takbenda. , Pub. L. No. 270/P/2014
(2014). Republik Indonesia: kemendikbud.go.id.

Ketaren, I. (2017). Gastronomi Upaboga Indonesia. Jakarta: IGA Press.

Krisnadi, A. R. (2018). Gastronomi Makanan Betawi Sebagai Salah Satu Identitas Budaya Daerah. National Conference of Creative Industry, (September), 5-6. https://doi.org/10.30813/ncci.v0i0.122 1

López, T. E. H., Hernández, Y. C., Sánchez, L. M. C., \& Pastaz, M. M. V. (2019). Gastronomic Tourism: Attitudes, Motivations and Satisfaction of the Visitor in Cantons of Tungurahua, Ecuador. American Journal of Industrial and Business Management, 09(03), 699-719. https://doi.org/10.4236/ajibm.2019.93 047

Meyers, K., \& Zalukhu, S. (2009). Ekowisata: Panduan Dasar Pelaksanaan. Jakarta: UNESCO Office. Retrieved from https://unesdoc.unesco.org/ark:/48223/ pf0000185506

Nikmah, N. F., Sudono, A., \& Fajri, I. (2019). Analysis of Millennial Consumption Behavior Factors and Their Interest in Visiting Sundanese Restaurants in Bandung. Gastronomy Tourism Journal, 5(2), 1-13.

Palupi, S., \& Fitri, A. (2019). Pendoman Pengembangan Wisata Kuliner. Jakarta: Kementrian Pariwisata dan Ekonomi Kreatif Republik Indonesia. Retrieved from https://disbudparpora.ponorogo.go.id/ wisata-kuliner/

Pitana, I. G., \& Diarta, I. K. S. (2009). Pengantar Ilmu Pariwisata. Yogyakarta: Andi Offset.

Pratomo, A. (2020). Sayur Besan. Retrieved 
October 22, 2020, from Travelink Magazine website: travelinkmagz.com/2020/04/sayurbesan/

Raco, J. . (2010). BAB I Pengertian Tujuan dan Latar Belakang Penelitian Kualitatif. In Metode Kualitatif (Jenis, Karakteristik, dan Keunggulannya). Jakarta: Grasindo.

Soeroso, A., \& Turgarini, D. (2020). Culinary Versus Gastronomy. EJournal of Tourism, 7(2), 193. https://doi.org/10.24922/eot.v7i2.6053 7

Syarifudin, D., Noor, C. M., \& Rohendi, C. (2017). Memaknai Kuliner Lokal Sebagai Daya Tarik Wisaya. Abdimas, 1(1), 4-8. https://doi.org/https://doi.org/10.31294 /jabdimas.v1i1.2866

Turgarini, D. (2018). Gastronomi Sunda sebagai Daya Tarik Wisata di Kota Bandung. Universitas Gadjah Mada.

Wijayanti, A. (2020). Pengantar Pariwisata dan Perhotelan. Yogyakarta: Universitas Bina Sarana Informatika. Retrieved from http://books.google.com/books?id=Kz xaq1D5-RcC\&pgis=1

World Tourism Organization. (2017). Second Global Report on Gastronomy Tourism. In Affiliate Members Report, Volume sixteen - Second Global Report on Gastronomy Tourism. Madrid: UNWTO. Retrieved from http://cf.cdn.unwto.org/sites/all/files/p df/gastronomy_report_web.pdf\%0Ahtt ps://doi.org/10.18111/9789284418701

Yoeti, O. (1996). Pengantar Ilmu Pariwisata. Bandung: Angkasa. 